\title{
GROWTH AND PHOTOSYNTHETIC EFFICIENCY OF Atriplex nummularia UNDER DIFFERENT SOIL MOISTURE AND SALINE TAILINGS ${ }^{1}$
}

\author{
ALINE SHEYLA LEAL DE OLIVEIRA ${ }^{2 *}$, EDUARDO SOARES DE SOUZA ${ }^{2}$, LUIZ GUILHERME MEDEIROS \\ PESSOA $^{2}$, SÉRGIO LUIZ FERREIRA-SILVA ${ }^{2}$, RODOLFO MARCONDES SILVA SOUZA ${ }^{3}$, ANTONIO CELSO \\ DANTAS ANTONINO ${ }^{3}$
}

\begin{abstract}
The disposal of the tailings (wastes) from desalinators is a growing problem, especially in semiarid regions, and it is necessary to study halophytes such as Atriplex nummularia for the reuse of these saline waters. Thus, the objective of this study was to evaluate the effect of the interaction between levels of soil water content and salinity of irrigation water, gas exchange and growth of Atriplex nummularia Lindl. The plants were cultivated in vases with soils under two moisture levels (50 and $100 \%$ of the field capacity) and irrigated with saline waters from dilution of the desalinator waste, to obtain the following electrical conductivities (EC) of $0.39 ; 1.54 ; 2.15 ; 2.79$; and $3.63 \mathrm{dS} \mathrm{m}^{-1}$. The experiment was conducted in a greenhouse for 160 days, with a triple factorial arrangement of $2 \times 5 \times 3$, in a randomized complete block design with four replications. The photosynthetic, biometric and plant biomass parameters were evaluated. Irrigation with saline water reduced the net photosynthetic rate $(A)$, stomatal conductance $\left(g_{s}\right)$, the effective quantum yield of photosystem II $(\Delta F / F m$ '), photochemical quenching $(q P)$ and the electron transport rate $(E T R)$ of the plants for the two conditions of soil moisture. However, it did not impair the efficiencies of water use (WUE) and carboxylation $(E I C)$ of plants. Plant growth rate and leaf biomass were stimulated under irrigation with saline water $\left(\mathrm{EC} \leq 3.63 \mathrm{dS} \mathrm{m}^{-1}\right)$, and when associated with soil moisture of $100 \% \mathrm{FC}$ leaf biomass gains $>100 \%$ were obtained.
\end{abstract}

Keywords: Photosynthesis. Halophyte. Water reuse. Salinity.

\section{CRESCIMENTO E EFICIÊNCIA FOTOSSINTÉTICA DE Atriplex nummularia SOB DIFERENTES UMIDADES DO SOLO E REJEITOS SALINO}

\begin{abstract}
RESUMO - O descarte do rejeito dos dessanilizadores é um problema crescente sobretudo nas regiões semiáridas, sendo necessário o estudo de plantas halófitas como a Atriplex nummularia para o reuso dessas águas salinas. Dessa forma, objetivou-se avaliar o efeito da interação entre níveis de teor de água solo e de salinidade da água de irrigação, nas trocas gasosas e no crescimento de Atriplex nummularia Lindl. As plantas foram cultivadas em vasos com solos sob dois níveis de umidade (50 e 100\% da capacidade de campo) e irrigadas com águas salinas provenientes de diluição de rejeito de dessalinizador obtendo as seguintes condutividades elétricas (EC) de 0,$39 ; 1,54 ; 2,15 ; 2,79 ;$ e $3,63 \mathrm{dS} \mathrm{m}^{-1}$. O experimento foi conduzido em casa de vegetação durante 160 dias, com o arranjo fatorial triplo de $2 \times 5 \times 3$, em delineamento em blocos ao acaso, com quatro repetições. Foram avaliados os parâmetros fotossintéticos, biométricos e a biomassa das plantas. A irrigação com água salina reduziu a taxa fotossintética líquida $(A)$, a condutância estomática $\left(g_{s}\right)$, o rendimento quântico efetivo do fotossistema II $\left(\Delta F / F m^{\prime}\right)$, o quenching fotoquímico $(q P)$ e a taxa de transporte de elétrons (ETR) das plantas para as duas condições de umidade do solo. Contudo, não prejudicou a eficiência do uso de água $(W U E)$ e de carboxilação $(E I C)$ das plantas. A taxa de crescimento das plantas e a biomassa foliar foi estimulada sob irrigação com água salina $\left(\mathrm{EC} \leq 3,63 \mathrm{dS} \mathrm{m}^{-1}\right)$, e quando associada a umidade de solo de $100 \%$ FC obteve ganhos de biomassa foliar $>100 \%$.
\end{abstract}

Palavras-chave: Fotossíntese. Halófita. Reuso de água. Salinidade.

\footnotetext{
${ }^{*}$ Corresponding author

${ }^{1}$ Received for publication in $01 / 27 / 2018$; accepted in $01 / 29 / 2019$

Paper extracted from the master dissertation of the first author.

${ }^{2}$ Academic Unit of Serra Talhada, Universidade Federal Rural de Pernambuco, Serra Talhada, PE, Brazil; oliveiraasl@gmail.com ORCID: 0000-0001-9955-6516, eduardo.ssouza@ufrpe.br - ORCID: 0000-0002-5488-5284, luiz.pessoa@ufrpe.br - ORCID: 0000-00031937-526X, sergio.luiz@ufrpe.br-ORCID: 0000-0003-3055-3258.

${ }^{3}$ Department of Nuclear Energy, National Observatory of Water and Carbon Dynamics in the Caatinga Biome, Universidade Federal de Pernambuco, Recife, PE, Brazil; rodolfomssouza@gmail.com - ORCID: 0000-0001-7551-0505, acda@ufpe.br - ORCID: 0000-0002-41209404.
} 


\section{INTRODUCTION}

At the global level, arid and semi-arid regions are more susceptible to salinization due to the association of soil characteristics with climatic factors, such as low and irregular rainfall precipitation, high temperatures and high potential evapotranspiration (PEDROTTI et al., 2015). In the Brazilian Semiarid region, water resources available in dams, lowlands and underground wells, the main reservoirs for agricultural use in the region, have their water quality compromised due to high content of salts (SOUSA NETO et al., 2011). It is estimated that more than 800 million hectares are affected by salinity (RENGASAMY, 2010), representing 6\% of the world's total area (GEISSLER et al., 2015) and more than $30 \%$ of irrigated soils in the world (FAO, 2011). In Brazil, it is estimated that 9 million hectares in the semiarid area of the northeast are affected by soil salinity, where about $11 \%$ of the irrigated land is salinized (DREGNE; CHOU, 1992).

As a result of the food demand of the growing world population, the intense exploitation of land and water resources has generated serious environmental and social imbalances. Among the various problems faced by the expansion of agricultural activities, salinity increase is one of the most important issues in world agriculture (DONG et al., 2010), and is even more worrying in arid and semi-arid regions. Soil salinity affects agricultural production with the inhibition of seed germination, plant growth and development due to osmotic effects, nutritional imbalance or toxicity of saline ions $\left(\mathrm{Na}^{+}\right.$and $\left.\mathrm{Cl}^{-}\right)$, resulting in reduction of the yields and quality of crops (SAIRAM; TYAGI, 2004); and the environment, with reduction of the remaining forest areas, increased exploitation of marginal lands and pollution of water sources (PEDROTTI et al., 2015).

The need for better quality water, both for agricultural use and for human consumption, has increased the use of desalinators in the region, which come to launch between 40 and $60 \%$ of saline tailings (wastes) in the environment, contributing to the contamination of the soil and groundwater (PORTO; AMORIM; SILVA JUNIOR, 2001; SOUSA NETO et al., 2011). In view of this fact, it is necessary to establish strategies for the disposal of these tailings, and an alternative would be the mixture of saline water from the tailings of desalinators with water of low salinity (fresh water) for irrigation purposes (CHOUDHARY; GRATTAN; MINHAS, 2011). Thus, the use of this mixture in the irrigation of halophyte plants of the genus Atriplex, constitutes a low-cost and promising technique for semiarid regions (LEAL et al., 2008; SANTOS et al., 2011).

Atriplex nummularia is a species of great importance for this purpose due to its adaptability to salinity and water deficiency. Several studies have investigated water and saline stresses separately, but few have evaluated their interactions (GLENN et al., 2012). It is necessary to investigate the performance of Atriplex to salts in the presence of low and high water content in the soil, as well as to investigate the physiology of tolerance to water and saline stresses, in order to understand the crop regarding the limits and compensations of tolerance to salts. In this sense, photosynthetic rates are among the main metabolic phenomena affected by water and saline stress (GLENN et al., 2012).

Based on the tolerance of Atriplex to salinity, it is assumed that the higher water availability associated with higher salt concentration in irrigation water, maximizes the growth and production of biomass by the influence of photosynthetic processes. Studying the interactive effect between soil moisture levels and salinity helps to understand how physiological and growth responses interfere with Atriplex productivity, considering that water is an important and limiting element in arid and semiarid regions. In view of the above, the objective was to evaluate the possible effect of the interaction between soil moisture levels and irrigation water salinity on gaseous exchange and growth in Atriplex plants.

\section{MATERIAL AND METHODS}

The experiment was conducted in a greenhouse at the Serra Talhada Academic Unit of the Federal Rural University of Pernambuco (UAST/ UFRPE), municipality of Serra Talhada-PE ( $7^{\circ} 57^{\prime}$ 10.8 " $\mathrm{S}$ and $\left.38^{\circ} 17,39.55^{\prime \prime} \mathrm{W}\right)$. The study period was from $12 / 10 / 2016$ to $22 / 03 / 2017$, totaling 160 days of evaluation. The climate of the study area according to the Köpen classification is of type BSWH' (hot and dry), with average annual precipitation of 632 $\mathrm{mm}$, with the rainy period from January to April, with about $65 \%$ of the annual rainfall, with the occurrence of temperatures higher than $32^{\circ} \mathrm{C}$ from November to January (COSTA et al., 2015). The average monthly maximum temperature varies from 23.6 to $27.7^{\circ} \mathrm{C}$ and the minimum from 18.4 to $21.6^{\circ} \mathrm{C}$ (COSTA et al., 2015).

The experimental period was characterized by mean daily temperature of $28.99 \pm 2.02^{\circ} \mathrm{C}$, with a maximum of $34.47 \pm 2.20^{\circ} \mathrm{C}$ and a minimum of $19.87 \pm 1.98^{\circ} \mathrm{C}$, in the external environment of the greenhouse. The mean daily relative humidity was $42.32 \pm 11.34 \%$, with a maximum and minimum of $78.63 \pm 11.31 \%$ and $17.93 \pm 10.67 \%$, respectively. During the 160 days it rained $213.2 \mathrm{~mm}$, with October and November being the months with the lowest rainfall of 0.2 and $6.6 \mathrm{~mm}$, respectively, and February the month of highest accumulated value with $100.6 \mathrm{~mm}$ (INMET, 2018) (Figure 1).

The surface layer $(0-20 \mathrm{~cm})$ of a non-saline and non-sodic haplic Cambisol (EMBRAPA, 2013) 
(RICHARDS, 1954) was used, of sandy loam textural class (Table 1). This material was dried in air, passed in a $4 \mathrm{~mm}$ sieve, homogenized and packaged in vases $30.5 \mathrm{~cm}$ high and $26 \mathrm{~cm}$ in diameter with capacity for $20 \mathrm{~kg}$ of dry soil. Soil samples were collected at the beginning, for characterization, and at the end of the experiment, to compare the chemical attributes after the application of treatments.

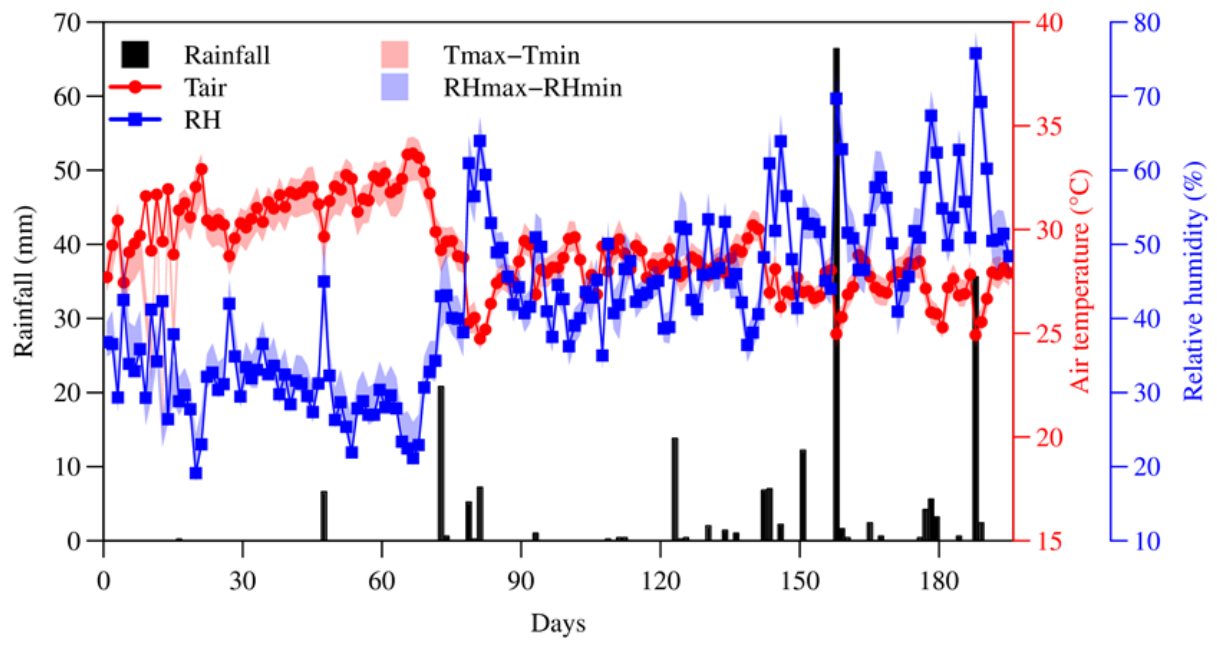

Figure 1. Mean daily temperature values (Tair $\left.{ }^{\circ} \mathrm{C}\right)$, relative humidity $(\mathrm{RH} \%)$ and rainfall $(\mathrm{mm})$ recorded at the site during the experiment (INMET, 2018).

Table 1. Characterization of the physical and chemical attributes of the Haplic Cambisol used in the experiment.

\begin{tabular}{|c|c|c|c|c|c|}
\hline \multirow{2}{*}{\multicolumn{2}{|c|}{ Physical attributes }} & \multicolumn{4}{|c|}{ Chemical attributes } \\
\hline & & \multicolumn{2}{|l|}{ Saturation extract } & \multicolumn{2}{|l|}{ Sortive complex } \\
\hline Coarse sand $\left(\mathrm{g} \mathrm{kg}^{-1}\right)$ & 384.1 & $\mathrm{EC}_{\mathrm{es}}{ }^{4}\left(\mathrm{dS} \mathrm{m}^{-1}\right)$ & 0.47 & $\mathrm{pH}$ & 7.4 \\
\hline Fine sand $\left(\mathrm{g} \mathrm{kg}^{-1}\right)$ & 320.8 & $\mathrm{Ca}^{2+}\left(\mathrm{mmol}_{\mathrm{c}} \mathrm{L}^{-1}\right)$ & 9.73 & $\mathrm{Ca}^{2+}\left(\mathrm{cmol}_{\mathrm{c}} \mathrm{kg}^{-1}\right)$ & 4.41 \\
\hline Silt $\left(\mathrm{g} \mathrm{kg}^{-1}\right)$ & 181.2 & $\mathrm{Mg}^{2+}\left(\mathrm{mmol}_{\mathrm{c}} \mathrm{L}^{-1}\right)$ & 3.72 & $\mathrm{Mg}^{2+}\left(\mathrm{cmol}_{\mathrm{c}} \mathrm{kg}^{-1}\right)$ & 0.88 \\
\hline Clay $\left(\mathrm{g} \mathrm{kg}^{-1}\right)$ & 113.9 & $\mathrm{Na}^{+}\left(\mathrm{mmol}_{\mathrm{c}} \mathrm{L}^{-1}\right)$ & 4.53 & $\mathrm{Na}^{+}\left(\mathrm{cmol}_{\mathrm{c}} \mathrm{kg}^{-1}\right)$ & 0.39 \\
\hline $\mathrm{D}_{\mathrm{s}}{ }^{1}\left(\mathrm{~g} \mathrm{~cm}^{-3}\right)$ & 1.56 & $\mathrm{~K}^{+}\left(\mathrm{mmol}_{\mathrm{c}} \mathrm{L}^{-1}\right)$ & 5.02 & $\mathrm{~K}^{+}\left(\mathrm{cmol}_{\mathrm{c}} \mathrm{kg}^{-1}\right)$ & 0.54 \\
\hline $\mathrm{D}_{\mathrm{p}}^{2}\left(\mathrm{~g} \mathrm{~cm}^{-3}\right)$ & 2.67 & $\operatorname{RAS}^{5}\left(\mathrm{mmol}_{\mathrm{c}} \mathrm{L}^{-1}\right)^{0,5}$ & 1.75 & $\mathrm{CEC}^{6}\left(\mathrm{cmol}_{\mathrm{c}} \mathrm{kg}^{-1}\right)$ & 6.22 \\
\hline $\mathrm{P}_{\mathrm{t}}^{3}(\%)$ & 41 & - & - & $\mathrm{P}\left(\mathrm{mg} \mathrm{kg}^{-1}\right)$ & 62.04 \\
\hline- & - & - & - & $\operatorname{PST}^{7}(\%)$ & 6.27 \\
\hline
\end{tabular}

${ }^{1}$ Soil density; ${ }^{2}$ Particle density; ${ }^{3}$ Total porosity; ${ }^{4}$ Saturation extract eletric conductivity; ${ }^{5}$ Sodium adsorption ratio;

${ }^{6}$ Cation exchange capacity; ${ }^{7}$ Sodium exchange percentage.

Soil moisture in the field capacity was standardized for vases according to the methodology of Casaroli and Van Lier (2008). Four vases were immersed with soil in water for 24 hours for soil saturation. Then the vases were covered to avoid evaporation and the drying procedure was initiated through drainage of the vases. The vases were weighed at intervals of $0 ; 12.27 ; 23.83 ; 36.12 ; 47.75$; $59.0 ; 70.68 ; 81.72 ; 92.93$ and 116.45 hours after saturation. The moisture was obtained by the difference between the initial mass of the soil/vase set and the mass obtained in the previous intervals. The moisture in the field capacity was obtained by adjusting the parameters of equation 1 to the data of the variation of the humidity in the time:

$$
\theta=\theta_{f}+\left(\theta_{0}-\theta_{f}\right) \cdot \exp \left(-t / t_{c}\right)
$$

where $\theta_{f}$ is the water content $\left(\mathrm{cm}^{3} \mathrm{~cm}^{-3}\right)$ when $t$ tends to infinity, $\theta_{0}$ is the initial water content $\left(\mathrm{cm}^{3} \mathrm{~cm}^{-3}\right)$ at time zero and $t_{c}$ is the the time interval (h) that $\theta_{0}$ reduces $1 / \mathrm{e}(\sim 0.368)$ times from the initial value. For the soil used, the moisture in the field capacity (FC) was $0.27 \quad\left(\mathrm{~cm}^{3} \mathrm{~cm}^{-3}\right)$ corresponding to $100 \% \mathrm{FC}$ and $0.135\left(\mathrm{~cm}^{3} \mathrm{~cm}^{-3}\right)$ corresponding to $50 \% \mathrm{FC}$.

The saline tailings used came from the 
Instituto Agronômico de Pernambuco (IPA), located in the municipality of Serra Talhada-PE. The plants were irrigated with different dilutions of saline tailings using good quality water. At each irrigation, samples of the water used in each treatment were collected, corresponding to the following average electrical conductivities (EC): $0.39 \pm 0.07 \mathrm{dS} \mathrm{m}^{-1}$ for the control ( $100 \%$ of water with good quality); 1.54 $\pm 0.05 \mathrm{dS} \mathrm{m}^{-1}$ (25\% saline tailings); $2.15 \pm 0.07 \mathrm{dS} \mathrm{m}$ ${ }^{-1}$ (50\% saline tailings); $2.79 \pm 0.18 \mathrm{dS} \mathrm{m} \mathrm{m}^{-1}(75 \%$ saline tailings) and $3.63 \pm 0.12 \mathrm{dS} \mathrm{m}^{-1}(100 \%$ saline tailings). The treatments were arranged in randomized blocks using a triple factorial scheme ( $2 \times 5 \times 3)$, with: 2 soil water contents $\times 5$ EC levels $\left(\mathrm{dS} \mathrm{m} \mathrm{m}^{-1}\right)$ of the irrigation water $\mathrm{x} 3$ time intervals (17, 46 and 79 days), with four replicates each.

Atriplex seedlings aged 180 days were used, propagated by cuttings in organic compost substrate and sand (2:1). In the final vases, the seedlings were irrigated with non-saline water for 12 days, when the treatments were initiated with saline water. The volume of water returned weekly was calculated based on two reference vases (without plants) maintained with the two soil water contents (50 and $100 \%$ FC). Before each irrigation, the residual water content of the soil of the reference vases was determined, to know the replacement volume required for the soils of the potted plants to reach the specific water contents (50 and 100\% FC).

Gaseous exchanges were measured at 17, 46 and 79 days of saline induction in the 40 Atriplex plants, where it was determined: the net photosynthetic rate $\left(A-\mu \mathrm{mol} \mathrm{CO}_{2} \mathrm{~m}^{-2} \mathrm{~s}^{-1}\right)$, the stomatal conductance $\left(g_{s}-\mathrm{mol} \mathrm{H}_{2} \mathrm{O} \mathrm{m} \mathrm{m}^{-2} \mathrm{~s}^{-1}\right)$, the efficiency of water use $\left(W U E-\left(\mu \mathrm{mol} \mathrm{CO}_{2} \mathrm{~m}^{-2} \mathrm{~s}^{-1} /\right.\right.$

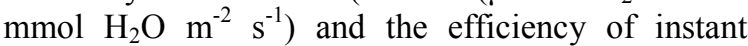
carboxylation (EIC - $\mu \mathrm{mol} \mathrm{CO}_{2} \mathrm{~m}^{-2} \mathrm{~s}^{-1} / \mu \mathrm{mol} \mathrm{CO}_{2}$ $\mathrm{mol}^{-1}$ ). Water use efficiency (WUE) was obtained by the relationship between the net photosynthetic rate and transpiration $(A / T)$, and the efficiency of instant carboxylation $(E I C)$ by the ratio between the net photosynthetic rate and the intracellular concentration of $\mathrm{CO}_{2}\left(A / C_{i}\right)$.

The readings were taken during the morning $(9: 00-12: 00 \mathrm{~h})$, in fully expanded leaves of the middle third of the plants, with an infrared gas analyzer (IRGA), model Licor Li 6400 XT, under light and concentration of environmental $\mathrm{CO}_{2}(380 \mathrm{ppm})$, and photosynthetically active radiation of $1000 \mu \mathrm{mol} \mathrm{m} \mathrm{m}^{-2} \mathrm{~s}^{-1}$. The chlorophyll a fluorescence parameters were measured together with the gaseous exchanges using a fluorometer coupled to IRGA. Also calculated were the effective quantum yield of photosystem II $\left(\Delta F / F m^{\prime}\right)$ (SCHREIBER et al., 1998), photochemical quenching $(q P)$ (VAN KOOTEN; SNEL, 1990) and the electron transport rate $(E T R)$. The gaseous exchanges were measured for a period of 79 days because the stabilization of the photosynthetic variables occurred until that moment. Thus, irrigation with the treatments was maintained, plant growth was evaluated and only at the end of the experiment, was leaf water potential $\left(\Psi_{\mathrm{h}}\right)$, chlorophyll content and biomass determined. Plant growth rate was measured monthly, GR $\left(\mathrm{cm} \mathrm{day}^{-1}\right)$, and at the end of the experiment (160 days), the leaf water potential $\left(\Psi_{\mathrm{h}}\right)$, chlorophyll content and biomass of all plants were examined. The leaf water potential $\left(\Psi_{\mathrm{h}}\right)$ was measured between 5:00 - 6:00 h in the morning using a Scholander chamber (model 3005F01), with a pressure capacity of 100 bar. For this, we used the completely expanded leaves of the third branch, counted from the apex.

The contents of chlorophyll (Chl $a, \mathrm{Chl} b, \mathrm{Chl}$ total and the Chl $a / b$ ratio) were obtained for approximately $138 \mathrm{mg}$ of fresh leaves (MF plant ${ }^{-1}$ ), and extracted in $5 \mathrm{~mL}$ of $80 \%$ acetone (ARNON, 1949). The concentrations of chlorophylls were determined with the aid of a spectrophotometer (BioChrom) at absorbances of 645, 652 and $663 \mathrm{~nm}$, so that the final chlorophyll pigments were calculated (WHITHAM; BLAYDES; DEVLIN, 1971).

After 160 days of cultivation, Atriplex plants were collected, separating leaves, stems and roots, and placed in an oven with circulation of hot air at $65^{\circ} \mathrm{C}$ for 72 hours to determine the dry mass. Then, the soils in the vases were sampled for determination of the electrical conductivity of the saturated paste extract $\left(\mathrm{EC}_{\mathrm{es}}\right)$ and the soluble contents of $\mathrm{K}^{+}$and $\mathrm{Na}^{+}$, were analyzed by flame emission photometry (RICHARDS, 1954). The data obtained were subjected to analysis of variance by the F test ( $p<$ 0.05 ), and for comparison of averages the Tukey test $(\mathrm{p}<0.05)$ was used, and regression functions were adjusted. For analyses, we used the statistical program $\mathrm{R}$ version 3.0.1, and the package ExpDes.pt (R CORE TEAM, 2018).

\section{RESULTS AND DISCUSSION}

The gaseous exchanges of atriplex plants occurred differently in two moments (Figure 2): i) after 17 days of exposure to soil salinity, a decrease in gas exchanges $\left(A\right.$ and $\left.g_{s}\right)$ was initiated, which lasted up to 46 days, a response apparently associated with the osmotic effect of saline stress (Figures 2A, B, D and E); ii) From 46 to 79 days, gaseous exchanges reached stabilization in time, indicating an apparent acclimatization of the plants to salinity (Figures 2B, C, E and F). This response may be associated with high accumulation of organic and inorganic osmosolutes in this species when exposed to salinity, an essential physiological mechanism for osmoprotection (SILVEIRA et al., 2009). Thus, the prolonged maintenance of stomatal opening and assimilation of $\mathrm{CO}_{2}$ under salinity observed here must have occurred due to osmotic adjustment, as part of the salt stress tolerance process 
of these plants. The different amounts of salts brought by irrigation to vases with Atriplex, during a period of 17 days, did not interfere in the metabolism of the plants, according to the Tukey test $(\mathrm{p}<0.05)$ with the highest values of the net photosynthetic rate $(A)$ and the stomatal conductance $\left(g_{s}\right)$ for the two conditions of moisture (50 and 100\% FC), compared to 46 and 79 days. After 46 days, the effect of reducing the soil water content $(50 \% \mathrm{FC})$ associated with the salts through irrigation was more intense, reducing the mean values of $A$ (Figures $2 \mathrm{~B}$ and $\mathrm{C}$ ) and $g_{s}$ (Figures $2 \mathrm{E}$ and $\mathrm{F}$ ). The values of $A$ and $g_{s}$ from 46 to 79 days, despite decreasing with EC, only showed difference $(p<0.05)$ between the control $\left(0.39 \mathrm{dS} \mathrm{m}^{-1}\right)$ and the treatment with higher salinity $\left(3.63 \mathrm{dS} \mathrm{m}^{-1}\right)$.

Plants subjected to treatments (water content $\mathrm{x}$ salinity) did not differ in water use efficiency (WUE) (Figures 2G, $\mathrm{H}$ and I) and efficiency of instant carboxylation (EIC) (Figures 2J, K and L). The amount of salts brought by irrigation waters with different levels of EC did not interfere with the $W U E$ and $E I C$ values that remained constant over time. Atriplex has the ability to increase $W U E$ in response to salts by minimizing the amount of water that must be transpired for each assimilated carbon unit, resulting in increased growth efficiency (GLENN; BROWN; BLUMWALD, 1999). The decrease in transpiration is a consequence of the decrease in the $g_{s}$, resulting in less water loss by the plant, which in saline environment is difficult to absorb due to the reduction of the soil water potential (OLIVEIRA et al., 2017). However, this physiological phenomenon of $g_{s}$ reduction for $W U E$ maintenance is characterized as an adaptive mechanism of tolerance to excess salts in the soil solution, rather than merely a negative consequence of the influence of these ions (MEGDICHE et al., 2008).

On the other hand, the reduction of $g_{s}$ limits the uptake and diffusion of $\mathrm{CO}_{2}$ to the carboxylation sites, leading to a decrease in intracellular $\mathrm{CO}_{2}$ concentration and consequently to $A$ (GEISSLER et al., 2015), as observed in this study when subjecting plants to increase of salts in the soil via irrigation water. However, in the $\mathrm{C}_{4}$ metabolism of halophyte plants of the genus Atriplex, this decrease of $A$ does not occur in direct proportion, thus they manage to remain efficient in the process of water use and instant carboxylation (GLENN; BROWN; BLUMWALD, 1999). In addition to these characteristics, the species $A$. nummularia under saline stress may present changes in carbon metabolism resembling CAM plants, Crassulacean acid metabolism (CUNHA; RUIZ; FREIRE, 2015).

At 17 days of saline induction, the levels of salts deposited in the soil did not compromise the activity of photosystem II of the plants, presenting maximum values of the effective quantum yield of photosystem II $\left(\Delta F / F m^{\prime}\right)$, photochemical quenching $(q P)$ and the electron transport rate $(E T R)$ (Figures $3 \mathrm{~A}, 3 \mathrm{D}$ and $3 \mathrm{G})$. For this period, the increasing EC levels stimulated these photochemical parameters, differing from the other times, 46 and 79 days (Figure 3). The reduction of $\Delta F / F m^{\prime}$ is related to the photoinhibition process and consequent effect on photochemical efficiency, resulting in the reduction of $E T R$, which in turn is influenced by abiotic factors such as soil salinity (BACELAR et al., 2007).

The reduction of the leaf water potential $\left(\Psi_{\mathrm{h}}\right)$ of the plants caused a decrease in $g_{s}$ over time, evidencing a decrease in the utilization rate of ATP and NADPH for $\mathrm{CO}_{2}$ assimilation, leading to the reduction of $\triangle F / F m^{\prime}$ (BENDALY et al., 2016). In the restriction of $\mathrm{CO}_{2}$ in leaves cells due to the reduction of $g_{s}$, the photosynthetic system is more susceptible to photochemical damage, where low $\mathrm{CO}_{2}$ assimilation rate can cause disturbances in the photochemical reactions, such as the occurrence of excessive light energy in photosystem II (SILVA et al., 2010). Thus, the low values of the fluorescence parameters of chlorophyll $a\left(\Delta F / F m^{\prime}, q P\right.$ and $\left.E T R\right)$ in Atriplex plants, are probably due to the reduction of $g_{s}$ and $A$ associated with the saline environment (SILVEIRA et al., 2010). Besides Atriplex being a halophyte, it has been found that this species may have reduced photochemical efficiency depending on the time of subjection to saline stress. 

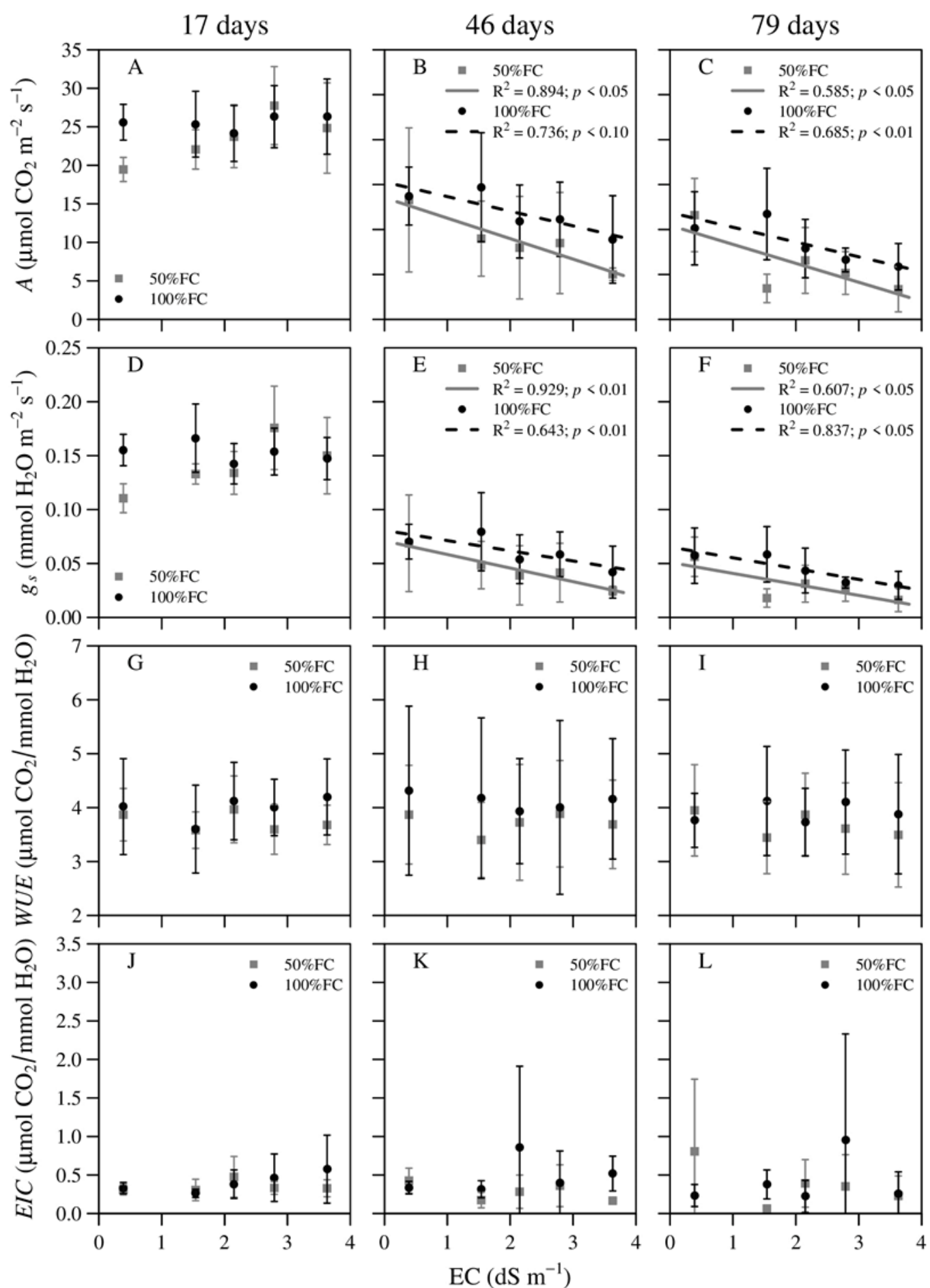

Figure 2. Net photosynthetic rate $(A)$, stomatal conductance $\left(g_{s}\right)$, efficiency of water use (WUE) and instantaneous carboxylation (EIC) in Atriplex nummularia L., after 17, 46 and 79 days of subjection to irrigation with increasing levels of salinization (EC equal to $0.39 ; 1.54 ; 2.15 ; 2.79$ and $3.63 \mathrm{dS} \mathrm{m}^{-1}$ ) and two soil water contents (50 and $\left.100 \% \mathrm{FC}\right)$. 

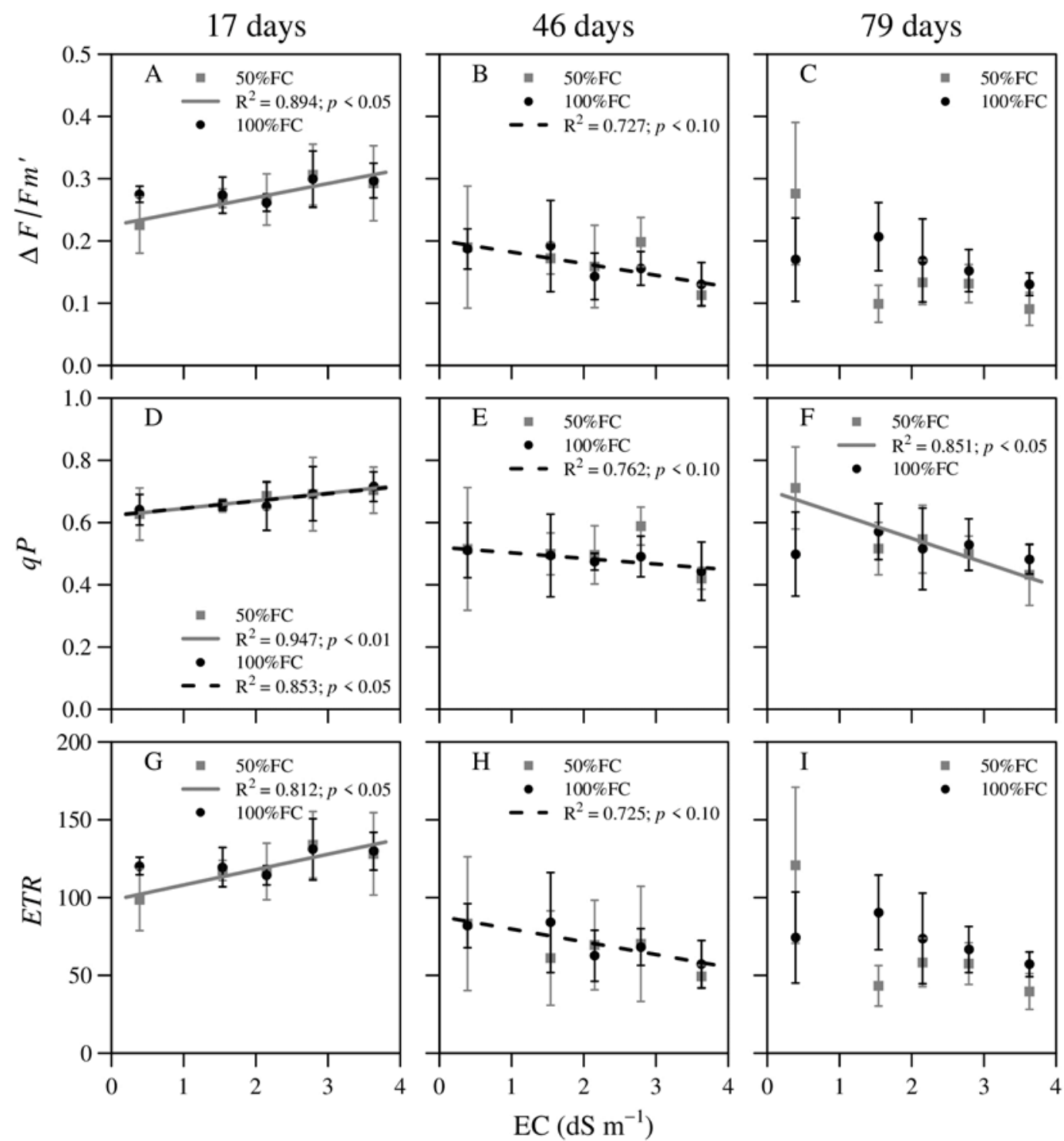

Figure 3. Effective quantum yield $\left(\Delta F / F m^{\prime}\right)$, photochemical quenching $(q P)$ and the electron transport rate $(E T R)$ in $A$. nummularia L., after 17, 46 and 79 days subjection to irrigation with increasing levels of salinization (EC equal to 0.39 , $1.54,2.15,2.79$ and $3.63 \mathrm{dS} \mathrm{m}^{-1}$ ) and two soil water contents (50 and 100\% FC).

The total growth rate of the shoot (GR) of the plants presented mean values of 0.109 and $0.140 \mathrm{~cm}$ day $^{-1}$ for humidity conditions of 50 and $100 \% \mathrm{FC}$, respectively, differing by Tukey's test $(\mathrm{p}<0.01)$. At 115 days, plants with $50 \%$ FC had a greater mean decrease in GR $\left(0.076 \mathrm{~cm} \mathrm{day}^{-1}\right)$ than those with $100 \%$ FC $\left(0.151 \mathrm{~cm} \mathrm{day}^{-1}\right)$, differing by Tukey's test $(p<0.01)$. The reduction of $99 \%$ of GR in Atriplex plants with $50 \% \mathrm{FC}$, in comparison with those with $100 \% \mathrm{FC}$, is due to the lower water availability associated with the osmotic effect of the salts present in the soil. The decrease in GR in saline conditions may be associated with lower carbon assimilation as well as increased energy demand (ATP and NADPH), due to the osmosolute biosynthesis process required for osmotic adjustment (BELKHEIRI; MULAS, 2013). When exposed to salinity, the plants initially undergo water stress, which reduces shoot growth as a form of adaptation to stress (SINGH; SARKAR, 2014). In general, growth variables, such as growth rate and biomass production, are good indicators of the plants' ability to adapt to saline environments and/or with low water availability (BENDALY et al., 2016).

When confronted at different levels of EC of irrigation water, the chlorophyll levels (Chl $a$, Chl $b$, $\mathrm{Chl}$ total and $\mathrm{Chl} a / b)$ in the leaves of Atriplex did not show differences (Figure 4). On the other hand, the mean values of the respective chlorophyll a $100 \%$ FC contents decreased in 27, 24 and $13 \%$ for $\mathrm{Chl} a$, Chl total and $\mathrm{Chl} a / b$, in relation to the values at $50 \% \mathrm{FC}$. Thus, the addition of salts in the soil for 160 days via irrigation water with $\mathrm{EC} \leq 3.63 \mathrm{dS} \mathrm{m}^{-1}$, only interfered in the photochemical processes of the plants maintained at $100 \% \mathrm{FC}$.

The reduction of photosynthetic pigments is 
related to the competition of $\mathrm{Na}^{+}$ions with $\mathrm{Mg}^{2+}$, during the absorption process, affecting the synthesis and maintenance of the chlorophyll content in the leaves of the plants. Chl $a$ is responsible for the photochemical process in chloroplasts and its reduction and/or degradation compromises the photochemical efficiency of the plants. Salinity may affect the concentration of chlorophyll in the leaves of plants by inhibiting chlorophyll synthesis or accelerating its degradation (TAIZ; ZAIGER, 2010).
The degradation of photosynthetic pigments is initiated by external factors, such as water stress, salinity, temperature, excessive luminosity, ethylene increases, and $\mathrm{pH}$ of very acidic tissues (STREIT et al., 2005). The concentration of Chl $a$ and $b$ in Atriplex plants reduces when salinity levels are above 100 mmol $_{\mathrm{c}} \mathrm{L}^{-1}$ of $\mathrm{NaCl}$ (ARAÚJO et al., 2006; GEISSLER et al., 2015), a concentration of salinity lower than that of the present study.
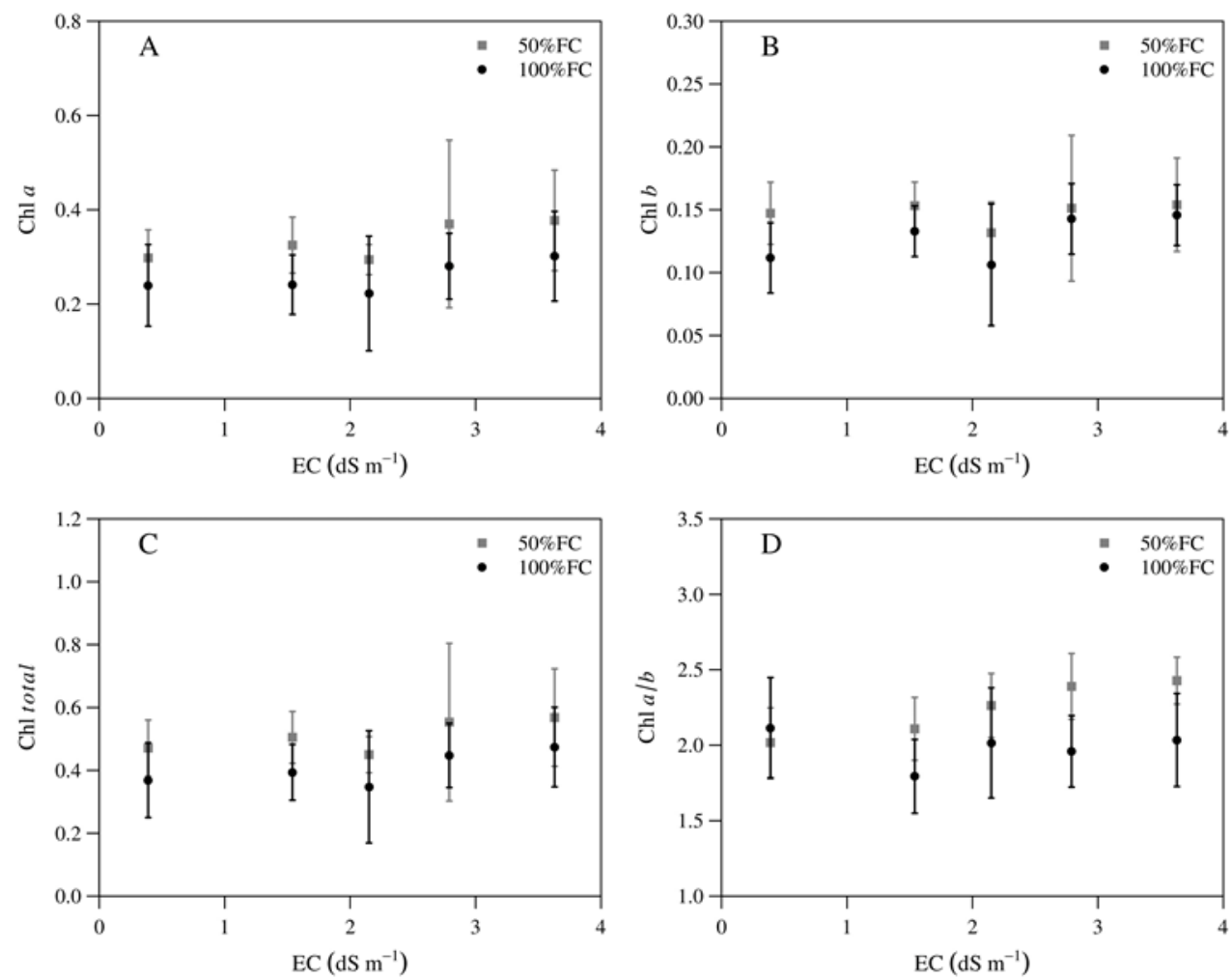

Figure 4. Content of chlorophyll a (Chl $a$ ), chlorophyll b (Chl b), total chlorophyll (Chl total) and the ratio of chlorophyll $a$ and $b(\mathrm{Chl} a / b)$ in $A$. nummularia $\mathrm{L}$., after 160 days subjection to irrigation with increasing levels of salinization (EC equal to $0.39 ; 1.54 ; 2.15 ; 2.79$ and $\left.3.63 \mathrm{dS} \mathrm{m}^{-1}\right)$ and two soil water contents $(50 \%$ and $100 \% \mathrm{FC})$.

Even Atriplex, after having its $A$-rate and the Cha-fluorescence reduced by the salts present in the soil solution from salt water irrigation over time, the plants were able to perform osmotic adjustment by expressing a positive response in the growth and production of shoot biomass (Figure 5), thus confirming the halophyte properties of tolerance to excess salts of the species.

These results can be justified by two factors: i) Atriplex, a $\mathrm{C}_{4}$ metabolism plant, reduces stomatal opening to reduce water losses during the day, due to high irradiance, high temperatures, salinity and water stress. However, it maintains active and efficient photosynthetic rates, that is, even with the reduction of $g_{s}\left(\mathrm{~mol} \mathrm{H}_{2} \mathrm{O} \mathrm{m}^{-2} \mathrm{~s}^{-1}\right)$ can capture atmospheric $\mathrm{CO}_{2}$, the main constituent for biomass synthesis (GLENN; BROWN; BLUMWALD, 1999; TAIZ; ZAIGER, 2010; CUNHA; RUIZ; FREIRE, 2015); ii) the change in the carbon metabolism of Atriplex plants from $\mathrm{C}_{4}$ to the Crassulaceae acid metabolism (CAM), makes it more efficient in the use of water, inducing the reduction of $g_{\mathrm{s}}$ during the day and increase during the night, the assimilation of $\mathrm{CO}_{2}$ both in the daytime and at night (CUNHA; RUIZ; FREIRE, 2015).

In soil with water content at $100 \% \mathrm{FC}$, the increase of salts in the irrigation water promoted increases in the dry mass of Atriplex leaves of 34, 58,119 and $108 \%$ in relation to the control (Figure 5A). These results evidenced their high adaptability to saline environments, corroborating with Geissler et al. (2015), Melo et al. (2016) and Silva et al. (2016).

The dry mass of the stems and roots presented mean values of 16.52 and $7.64 \mathrm{~g}$, respectively, in humidity conditions of $50 \% \mathrm{FC}$, and 27.58 and 
$11.97 \mathrm{~g}$, in $100 \% \mathrm{FC}$, differing by the Tukey test $(\mathrm{p}<$ $0.01)$. When subjected to soil water content of $100 \%$ $\mathrm{FC}$, there was an increase of $40.1 \%$ in the dry mass of the stem and $36.17 \%$ of the root (Figures $5 \mathrm{~B}$ and 5C). The salinity levels tested did not have a significant effect on the dry biomass of the stem, roots and the shoot/root ratio of Atriplex. However, water stress was verified in the plants with the lowest soil water content $(50 \%$ FC) (Figures 5B, 5C and $5 \mathrm{D})$. The plants presented a greater accumulation of dry matter when irrigated with water of higher EC (2.79 and $\left.3.63 \mathrm{dS} \mathrm{m}^{-1}\right)$ and under soil moisture of $100 \% \mathrm{FC}$.

These results show that with the water content at $100 \% \mathrm{FC}$, the salts were more available in the soil solution, leading to a greater absorption by the roots. Thus, the transport of the salts to the shoot occurred more intensely, where these salts constituted essential elements, stimulating the growth and accumulation of the biomass of Atriplex plants (FLOWERS; COLMER, 2008), especially at 17 days.

Another relevant issue is that the tolerance of halophytes to salts may not require large metabolic energy expenditures in the processes of salts compartmentalization $\left(\mathrm{Na}^{+}\right.$and $\left.\mathrm{Cl}^{-}\right)$in the vacuoles of cells, which justifies the occurrence of high yields of these species in environments with high salinity (GLENN; BROWN; BLUMWALD, 1999).
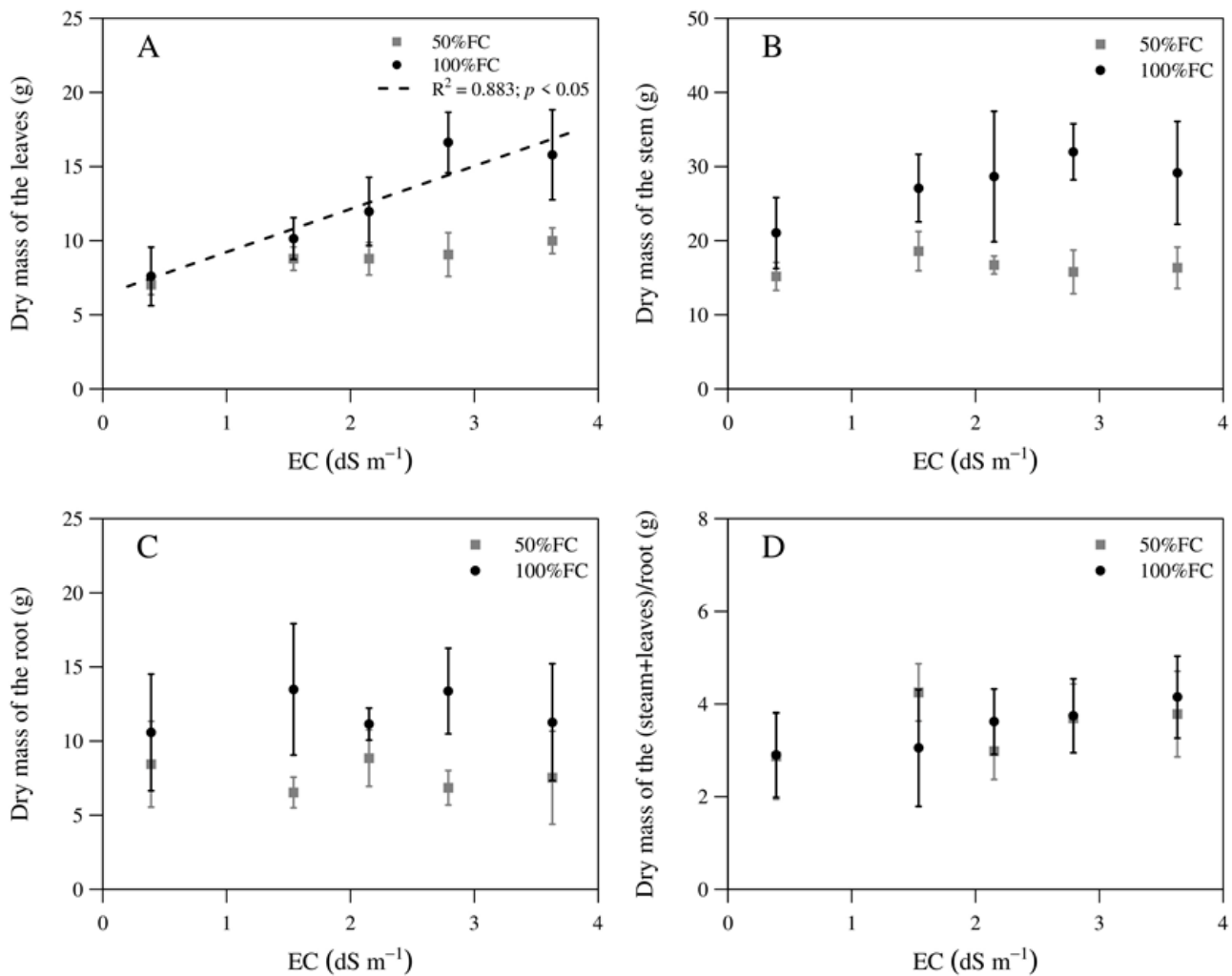

Figure 5. Dry mass of the leaves, stem and root and the relation of the dry mass of the shoot (stem + leaves) with the root in plants of Atriplex nummularia L., after 160 days of being subjected to irrigation with increasing levels of salinization (EC equal to $0.39 ; 1.54 ; 2.15 ; 2.79$ and $3.63 \mathrm{dS} \mathrm{m}^{-1}$ ) and two soil water contents (50 and $\left.100 \% \mathrm{FC}\right)$.

Thus, the adaptive responses of Atriplex plants under irrigation with saline water over time can be justified by the high tolerance to osmotic stress and high concentrations of salt in the soil solution, in addition to the ability to exclude salts from the shoot (SINGH; SARKAR, 2014), where for most species of the genus Atriplex it can be greater than $50 \%$ of all salts transported to the shoot through foliar epidermal trichomes (BELKHEIRI; MULAS, 2013).

As the EC levels of irrigation water were increased, there was an increase in the salt content (potassium and sodium) in the soil solution (Figure 6). With additions of $39.54,119.83,237.26$ and
$144.99 \%$ of potassium in the soil for the humidity of $50 \% \mathrm{FC}$ and $82.20,94.53,328.79$ and $227.07 \%$ for the humidity of $100 \% \mathrm{FC}$ in relation to the control (Figure 6A). Whereas for sodium the increase was in the order of $39.5,119.8,237.3$ and $145 \%$ for $50 \%$ FC and $82.2,94.5,328.8$ and $327.1 \%$ for $100 \% \mathrm{FC}$ (Figure 6B).

However, it is worth noting that even though Atriplex was more efficient in biomass production, according to the increase in the EC of irrigation water, soil salinization at the end of the study was observed for both soil moisture conditions (50 and $100 \%$ FC), mainly for greater soil moisture. 

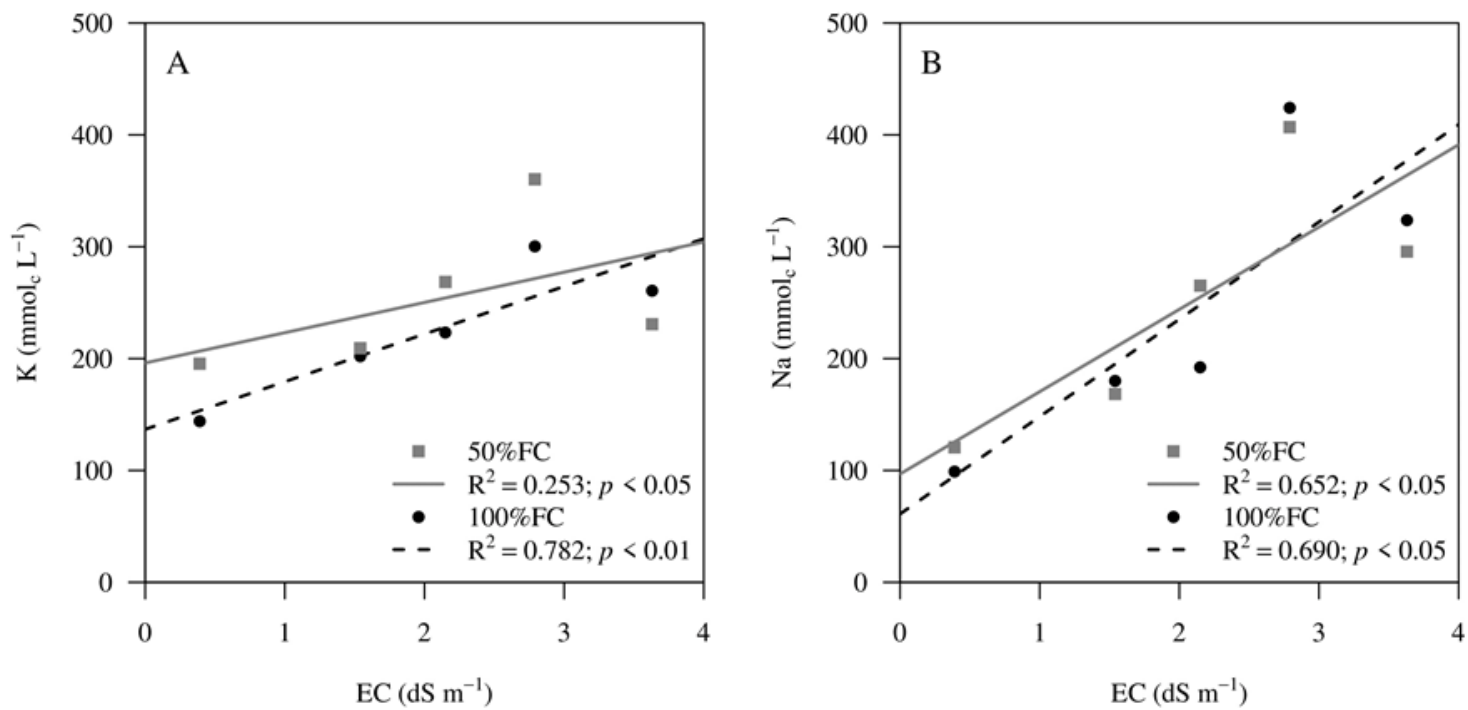

Figure 6. Potassium $\left(\mathrm{K}^{+}\right)$and sodium $\left(\mathrm{Na}^{+}\right)$contents of the saturated soil paste extract after 160 days of cultivation with Atriplex nummularia L., subjected to irrigation with increasing levels of salinization (EC equal to $0.39 ; 1.54,2.15,2.79$ and $\left.3.63 \mathrm{dS} \mathrm{m}^{-1}\right)$ and two soil water contents (50 and $\left.100 \% \mathrm{FC}\right)$.

There was a negative correlation of leaf water potential $\left(\Psi_{\mathrm{h}}\right)$ of Atriplex plants with the electrical conductivity of the extract of the soil saturation paste ( $\mathrm{EC}_{\mathrm{es}}$ ) (Figure 7). The $\Psi_{\mathrm{h}}$ of the plants decreases with increase of the $\mathrm{EC}_{\mathrm{es}}$ in the two conditions of humidity. This reduction of leaf $\Psi_{\mathrm{h}}$ can be attributed to high accumulation of salts in the leaf tissue, including the toxic ions $\mathrm{Na}^{+}$and $\mathrm{Cl}^{-}$, partly responsible for the osmotic adjustment mechanism in Atriplex plants exposed to salinity (SILVEIRA et al.,
2009). The soil water content at $100 \% \mathrm{FC}$ increased $\Psi_{\mathrm{h}}(-3.24 \mathrm{MPa})$ in the plants when compared to those with soil water content at $50 \% \mathrm{FC}(-3.41 \mathrm{MPa})$, differing by the Tukey test $(\mathrm{p}<0.01)$. In conditions of water limitation, accentuated with salinity, the decrease of $\Psi_{\mathrm{h}}$ in plant cells causes the roots to absorb water from a medium rich in soluble salts which are transported to the shoot, thereby increasing the gradient of the potential energies between the soil and the plant.

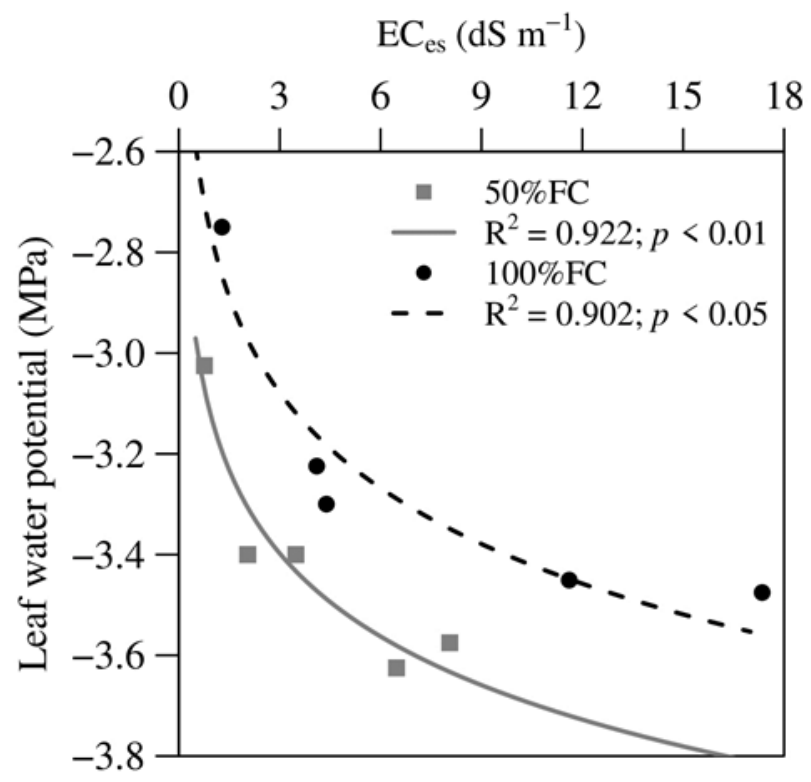

Figure 7. Relationship between the leaf water potential $\left(\Psi_{\mathrm{h}}\right)$ of Atriplex nummularia L. plants and the electrical conductivity of the saturated soil saturation paste extract $\left[\mathrm{EC}_{\mathrm{es}}\left(\mathrm{dS} \mathrm{m}^{-1}\right)\right]$ at the end of the experiment. 
Although Atriplex is highly tolerant to saline stress and has a relative potential for phytoremremediation practices (PORTO; AMORIM; SILVA JUNIOR, 2001; LEAL et al., 2008; SOUZA et al., 2011), it was observed that irrigation with saline water $\left(1.54-3.63 \mathrm{dS} \mathrm{m}^{-1}\right)$ contributed to soil salinization. With increase in the $\mathrm{EC}$ of the irrigation water there was an increment in the $\mathrm{EC}_{\mathrm{es}}$ of the soil as follows $168.67 ; 356.57 ; 748.90$ and $956.70 \%$ for $50 \% \mathrm{FC}$ and $241.97 ; 220.16 ; 1252.09$ and $803.80 \%$ for $100 \% \mathrm{FC}$, compared to the control at the end of the experiment (Figure 7). Although it is believed that its cultivation has contributed to the phytoextraction of salts in the soils of the vases, this extraction is very small compared to the amount introduced by irrigation. The irrigation of Atriplex for phytoremediation can be done with saline waters in the range of $0.175-1.5 \mathrm{dS} \mathrm{m}^{-1}$ (LEAL et al., 2008), less saline water than that used in this study.

On the other hand, the soil salts extraction capacity of this species may depend on the management employed, considering the successive cycles associated with its phytomass production potential. However, it is necessary to be conscious in the use of saline tailings in the cultivation of Atriplex, associating techniques such as the application of leaching, to mitigate the salinization of soils that receive the saline effluent.

\section{CONCLUSION}

After 17 days, the effect of irrigation with saline water $\left(\mathrm{EC} \leq 3.63 \mathrm{dS} \mathrm{m}^{-1}\right)$ caused the reduction of gaseous exchange and chlorophyll a fluorescence of the plant Atriplex nummularia L. in both soil moisture conditions (50 and 100\% FC); however, the efficiency of water use and carboxylation were not impaired.

There was reduction in the levels of Chlorophylls (Chl $a$, Chl total and $\mathrm{Chl} a / b$ ), due to the high levels of salts in the soil solution, resulting from irrigation with saline water over time, Atriplex plants responded well to the increase of soil moisture, to higher photosynthesis, growth and biomass when maintained at $100 \% \mathrm{FC}$.

The cultivation of atriplex irrigated with saline water $\left(1.54 \leq \mathrm{EC} \leq 3.63 \mathrm{dS} \mathrm{m}^{-1}\right)$ provided an increase in shoot biomass when compared to those irrigated with good quality water $\left(0.39 \mathrm{dS} \mathrm{m}^{-1}\right)$, especially when associated with humidity of $100 \%$ $\mathrm{FC}$, where it comes to have an increase of more than $100 \%$. Although Atriplex tolerated irrigation with wastes from water desalination, the use of this water promoted salinization of the soil, since the rate of entry of salts into the system was higher than the rate of exit by the extraction of the plant. In light of this, further research is needed to assess the reduction of environmental impacts.

\section{ACKNOWLEDGEMENTS}

We gratefully thank the Pernambuco State Research Support Foundation - FACEPE (grants: APQ-1196-5.03/15; IBPG-0262-5.01/15; APQ-02965.01/17; APQ-0498-3.07/17/NOWCDCB), the National Council for Scientific and Technological Development - CNPq (grants: 441305/2017-2; 312984/2017-0; 465764/2014-2/NOWCDCB) and the Coordination for the Improvement of Higher Education Personnel - CAPES (grants: 88887.136369/2017-00/NOWCDCB) for financial support and research fellowships. This work is part of National Observatory of Water and Carbon Dynamics in the Caatinga Biome (NOWCDCB) supported by FACEPE articulated with $\mathrm{CNPq}$ and the CAPES.

\section{REFERENCES}

ARAÚJO, S. A. M. et al. Salinity tolerance of halophyte Atriplex nummularia L. grown under increasing $\mathrm{NaCl}$ levels. Revista Brasileira de Engenharia Agrícola e Ambiental, v. 10, n. 4, p. 848-854, 2006.

ARNON, D. I. Copper enzymes in isolated chloroplasts: polyphenol-oxydase in Beta vulgaris. Plant Physiology, v. 24, n. 1, p. 1-15, 1949.

BACELAR, E. A. et al. Physiological behaviour, oxidative damage and antioxidative protection of olive trees grown under different irrigation regimes. Plant Soil, v. 292, s/n., p. 1-12, 2007.

BELKHEIRI, O.; MULAS, M. The effects of salt stress on growth, water relations and ion accumulation in two halophyte Atriplex species. Environmental and Experimental Botany, v. 86, n. 2, p. 17-28, 2013.

BENDALY, A. et al. Physiological and leaf metabolome changes in the xerohalophyte species Atriplex halimus induced by salinity, Plant Physiology and Biochemistry, v. 103, n. 6, p. 208 218, 2016.

CASAROLI, D.; VAN LIER, Q. J. Critérios para determinação da capacidade de vaso. Revista Brasileira de Ciência do Solo, v. 32, n. 1, p. 59-66, 2008.

CHOUDHARY, O. P.; GRATTAN, S. R.; MINHAS, P. S. Sustainable crop production using saline and sodic waters. In: LICHTFOUSE, E. (Ed.). Alternate Farming Systems, Biotechnology, Drought Stress and Ecological Fertilisation. Sustainable Agriculture Reviews, v. 6, Springer Dordrecht, New York, 2011, p. 293-318. 
COSTA, E. J. B. et al. Cultivo de sorgo em sistema de vazante com e sem cobertura do solo. Revista Brasileira de Milho e Sorgo, v. 14, n. 2, p. 182-195, 2015.

CUNHA, J. C.; RUIZ, H. A.; FREIRE, M. B. G. S. Adubação nitrogenada e fosfatada no cultivo de Atriplex nummularia. Universidade Federal de Viçosa, Viçosa, MG: Novas Edições Acadêmicas, $2015.96 \mathrm{p}$

DONG, H. et al. Unequal salt distribution in the root zone increases growth and yield of cotton. European Journal of Agronomy, v. 33, n. 4, p. 285-292, 2010.

DREGNE, H. E.; CHOU, N-T. Global desertification dimensions and costs. In: DREGNE, H. E. (Ed.). Degradation and restoration of arid lands. ICASALS, Texas Tech University, Lubbock, 1992, p. 249-282.

EMPRESA BRASILEIRA DE PESQUISA AGROPECUÁRIA - EMBRAPA. Sistema Brasileiro de Classificação de Solos. 3 ed. Rio de Janeiro, RJ: EMBRAPA Solos, 2013. 353 p.

FOOD AND AGRICULTURE ORGANIZATION OF THE UNITED NATIONS - FAO, 2011. Land and plant nutrition management service. Disponível em: <http://www.fao.org/land-water/en/ >. Acesso em: 29 abri. 2017.

FLOWERS, T. J.; COLMER, T. D. Salinity tolerance in halophytes. New Phytologist, v. 179, n. 4, p. $945-963,2008$.

GEISSLER, N. et al. Elevated atmospheric $\mathrm{CO}_{2}$ concentration leads to different salt resistance mechanisms in a $\mathrm{C}_{3}$ (Chenopodium quinoa) and a $\mathrm{C}_{4}$ (Atriplex nummularia) halophyte. Environmental and Experimental Botany, v. 118, n. 10, p. 67-77, 2015.

GLENN, E. P.; BROWN, J. J.; BLUMWALD, E. Salt tolerance and crop potential of halophytes. Critical Reviews in Plant Sciences, v. 18, n. 2, p. 227-255, 1999.

GLENN, E. P. et al. Comparison of salinity tolerance of three Atriplex spp. in well-watered and drying soils. Environmental and Experimental Botany, v. 83, n. 11, p. $62-72,2012$

INSTITUTO NACIONAL DE METEOROLOGIA INMET. Consulta Dados da Estação Automática: Serra Talhada (PE). Disponível em: <http:// www.inmet.gov.br/sonabra/

pg_dspDadosCodigo_sim.php?QTM1MA>. Acesso em: 05 jan. 2018.
LEAL, I. G. et al. Fitorremediação de solo salino sódico por Atriplex nummularia e gesso de jazida. Revista Brasileira de Ciência do Solo, v. 32, n. 3, p. 1065-1072, 2008 .

MEGDICHE, W. et al. Photosynthesis and photosystem 2 efficiency of two salt-adapted halophytic seashore Cakile maritima ecotypes. Photosynthetica, v. 46, n. 3, p. 410-419, 2008.

MELO, H. F. et al. Growth, biomass production and ions accumulation in Atriplex nummularia Lindl grown under abiotic stress. Revista Brasileira de Engenharia Agrícola e Ambiental, v. 20, n. 2, p. 144-151, 2016.

OLIVEIRA, W. J. et al. Leaf gas exchange in cowpea and $\mathrm{CO} 2$ efflux in soil irrigated with saline water. Revista Brasileira de Engenharia Agrícola e Ambiental, v. 21, n. 1, p. 32-37, 2017.

PEDROTTI, A. et al. Causas e consequências do processo de salinização dos solos. Revista Eletrônica em Gestão, Educação e Tecnologia Ambiental, v. 19, n. 2, p. 1308-1324, 2015.

PORTO, E. R.; AMORIM, M. C. C.; SILVA JUNIOR, L. G. A. Uso de rejeito de dessalinização de água salobra para irrigação da erva-sal (Atriplex nummularia). Revista Brasileira de Engenharia Agrícola e Ambiental, v. 5, n. 1, p. 111-114, 2001.

R CORE TEAM. R: A language and environment for statistical computing. $R$ Foundation for Statistical Computing. 2018. Disponível em: $<$ http://ww1.rproject.org/?subid1=d5aeae72-02f011e8-8079-4f572a0015ce>. Acesso em: 08 jan 2018.

RENGASAMY, P. Soil processes affecting crop production in salt-affected soils. Functional Plant Biology, v. 37, s/n., p. 613-620, 2010.

RICHARDS, L. A. Diagnostics and improvement of salinity and alkali soil. Washington, D.C: United States Salinity Laboratory, United States Department of Agriculture, 1954. 160 p. (Handbook, 60).

SANTOS, K. C. F. et al. Atividade biológica em solo salino sódico saturado por água sob cultivo de Atriplex nummularia. Revista Ciência Agronômica, v. 42, n. 3, p. 619-627, 2011.

SAIRAM, R. K.; TYAGI, A. Physiology and molecular biology of salinity stress tolerance in plants. Currente Science, v. 86, n. 3, p. 407-421, 2004.

SCHREIBER, U. et al. Chlorophyll fluorescence as a diagnostic tool: basics and some aspects of practical relevance. In: RAGHAVENDRA, A. S. (Ed.). 
Photosynthesis: a comprehensive treatise. Cambridge: Cambridge University Press, 1998. p. 320-336.

SILVA, E. N. et al. Comparative effects of salinity and water stress on photosynthesis, water relations and growth of Jatropha plants. Journal of Arid Environments, v. 74, n. 10, p. 1130-1137, 2010.

SILVA, Y. J. A. B. et al. Atriplex nummularia Lindl. as alternative for improving salt-affected soils conditions in semiarid environments: a field experiment. Chilean Journal Agricultural Research, v. 76, n. 3, p. 343-348, 2016.

SILVEIRA, J. A. G. et al. Mecanismos biomoleculares envolvidos com a resistência ao estresse salino em plantas. In: GHEYI, H. R.; DIAS, N. S.; LACERDA, C. F. (Eds.). Manejo da salinidade na agricultura: estudos básicos e aplicados. Fortaleza: INCTSal. 2010, cap. 11, p. 161180.

SILVEIRA, J. A. G. et al. Roots and leaves display contrasting osmotic adjustment mechanisms in response to $\mathrm{NaCl}$-salinity in Atriplex nummularia. Environmental and Experimental Botany, v. 66, n. 1, p. 1-8, 2009.

SINGH, D. P.; SARKAR, R. K. Distinction and characterisation of salinity tolerant and sensitive rice cultivars as probed by the chlorophyll fluorescence characteristics and growth parameters. Functional Plant Biology, v. 41, n. 7, p. 727-736, 2014.

SOUSA NETO, O. N. et al. Utilização do rejeito da dessalinização da água na produção de mudas de espécies da Caatinga. Revista Caatinga, v. 24, n. 4, p. 123-129, 2011.

SOUZA, E. R. et al. Fitoextração de sais pela Atriplex nummularia lindl. sob estresse hídrico em solo salino sódico. Revista Brasileira de Engenharia Agrícola e Ambiental, v. 15, n. 5, p. 477-483, 2011.

STREIT, M. N. et al. As clorofilas. Ciência Rural, v. 35, n. 3 , p. $748-755,2005$.

TAIZ, L.; ZEIGER, E. Plant physiology. 5 ed. Massachusetts, U. S. A. Sinauer Associates Inc., Publishers Sunderland, 2010. 782 p.

VAN KOOTEN, O.; SNEL, J. F. H. The use of clorophyll fluorescence nomenclature in plant stress physiology. Photosynthesis Research, v. 25, n. 3, p. 147-150, 1990.
WHITHAM, F. H.; BLAYDES, D. F.; DEVLIN, R. M. Experiments in plant physiology. New York, USA: Van Nostrand Reinhold, 1971. 254 p. 